\title{
Rzeź katolików w Krożach. Przyczynek do dziejów walki Polaków i Litwinów przeciwko rządom carskim w XIX wieku
}

„O pięć mil od Rosień, w sercu świętej Żmudzi jest mała mieścina, co od rzeki Krożęty - Krożami nazwaną została. Na wyniosłej i stromej górze, stoi starożytna fara, do której wierni wstępują po kilkudziesięciu stopniach kamiennych. U stóp góry, pieniąca się i szumiąca, płynie krętą wstęgą rzeczka Krożęta, a nad jej brzegami, małe domki z ogródkami, rozsypane jak bukiety. Za górą farnego kościoła, tuż za miasteczkiem, wyniosła góra Miedziokalnia wznosi swe czoło wśród pól i łąk, dawniej stuletnie rosły tam dęby, pamiętające może czasy, kiedy tam na cześć bogini Medżoima składali pogańscy Litwini upolowaną z łuków zwierzynę [...]. Uroczy to zakątek Litwy i pełen pamiątek"1. Takimi wzniosłymi słowami Helena Romer-Ochenkowska opisywała niewielką miejscowość, która stała się miejscem jednej z najokrutniejszych zbrodni władz carskich, dokonanej na ludności katolickiej.

Władze rosyjskie, po powstaniach wyzwoleńczych z lat 1830-1831 i 1863-1864, prowadziły szeroko zakrojone działania skierowane na zmniejszenie wpływów i znaczenia Kościoła katolickiego w tak zwanym Północno-Zachodnim Kraju Cesarstwa Rosyjskiego (Siewiero-Zapadnyj Kraj) oraz wzmocnienie pozycji religii państwowej, a więc Cerkwi prawosławnej. Od chwili przybycia do Wilna, w maju 1863 r., nowego generała-gubernatora Michała Nikołajewicza Murawiewa „Wieszatiela”, administracja rosyjska systematycznie zwalczała tak wyrazistą dominację katolicyzmu. Tym samym ograniczono swobodę poruszania się kleru z parafii do parafii, zaś w latach 1866-1867 zakazano organizowania uroczystych procesji w miastach oraz kościołach. W 1864 r. z kolei, ponownie zabroniono ustawiania przydrożnych krzyży, a także rozpoczęto akcję zamykania klasztorów i świątyń katolickich. W okresie od 1832 do 1893 r., tylko w diecezji żmudzkiej zlikwidowano 46 klasztorów, 22 kościoły oraz kaplice².

H. Romer, Swoi ludzie, Wilno 1922, s. 16-17.

T. Bairašauskaité, Z. Medišauskienè, R. Miknys, Lietuvos istorija, VIII Tomas: I Dalis, Devynioliktas amžius: visuomené ir valdżia, Vilnius 2011, s. 283; E. Vidmantas, Kražiu ivykiu išstakos, 
Władze bardzo uważnie przyglądały się nie tylko działalności duszpasterskiej prostego kleru, lecz w pierwszej kolejności obserwowano poczynania wysokich hierarchów kościelnych. W niemalże każdej większej akcji doszukiwano się objawów nieposłuszeństwa, opozycji oraz krzewienia nastrojów patriotycznych; uczucia te były przez duchowieństwo aktywnie pobudzane wśród ludu wierzącego. Duży niepokój wywołała aktywność biskupa ordynariusza żmudzkiego Mieczysława Leonarda Pallulona. To jemu właśnie udało się uzyskać zgodę na wizytację parafii w swojej diecezji, co było zakazane jeszcze w 1863 r. Kiedy w 1889 r. biskup odwiedzal parafie katolickie w powiecie jezioroskim, władze były zaskoczone rozmachem całego przedsięwzięcia. Generał-gubernator wileński Iwan Kachanow, 3 czerwca 1889 r. donosił ówczesnemu ministrowi spraw wewnętrznych, że w uroczystościach powitalnych brało udział powyżej 50 tys. osób. Biskup był witany przez tłumy wiernych, co zostało uznane za demonstrację polityczna, potwierdzająca ogromny wpływ kleru katolickiego, nie zważającego na jakiekolwiek represje ${ }^{3}$. Toteż walka z Kościołem nadal była aktualnym problemem w programie rusyfikacji guberni Kraju Północno-Zachodniego.

Gubernator kowieński Mikołaj Klingenberg 12 grudnia 1891 r. zawiadomił biskupa Pallulona, iż na mocy ukazu cesarskiego nastapiła kasata klasztoru Benedyktynek w Krożach na Żmudzi ${ }^{4}$. Oznajmił także, że przebywające w kościele przyklasztornym zakonnice ${ }^{5}$ miały opuścić jego mury i przeprowadzić się do klasztoru w Kownie. Postanowienie to uznano w opinii społecznej za działania skierowane przeciwko miejscowym Polakom oraz Litwinom, a także jako wymierzone w religię katolicką ${ }^{6}$. Warto wspomnieć, że świątynia należąca do klasztoru była uważana przez krożan za „kościół pański”, do którego najchętniej uczęszczali ziemianie $\mathrm{z}$ pobliskich dworów. Znaczna część

w: Lietuviu Kataliku Mokslo Akademijos Metraštis, t. VII, Vilnius 1994, s. 51; P. Čepenas, Naujuu laiku Lietuvos istorija, t. I, Vilnius 1992, s. 137 - 138; E. Vidmantas, Religinis tautinis sajüdis Żemaitijoje XIX a. pabaigoje, w: Lietuviu atgimimo istorijos studijos, t. 7, Atgimimas ir Kataliku Bažnyčia, Vilnius 1994, s. 123-126.

E. Vidmantas, Religinis tautinis sajudis Żemaitijoje, s. 121-122; E. Vidmantas, Religinis tautinis sajūdis Lietuvoje XIX a. antrojoje pusèje - XX a. pradžioje, Vilnius 1995, s. 74-75.

4 J. Skłodowski, Kroże zapomniane,,Ateny Żmudzkie", s. 36 (http://www.nimoz.pl/upload/wydawnictwa/cenne_bezcenne_utracone/2011_2/Strony_34-37.pdf.)

${ }^{5}$ W. Dobaczewska, Wilno $i$ Wileńszczyzna w latach 1863-1914. Dzieje ruchów spolecznych i politycznych, Wilno 1938, s. 21; Slownik geograficzny Królestwa Polskiego i innych krajów slowiańskich, t. 4, wyd. F. Sulimierski i W. Walewski, Warszawa 1880-1914, s. 720; zob. też J. B.[uszyński], Kroże. Ich przeszlość i stan obecny, Wilno 1872, s. 11-13, 32, 39, 51. Kościół zakonny benedyktynek pod wezwaniem Najświętszej Marii Panny Niepokalanego Poczęcia w Krożach, w powiecie rosieńskim, dekanacie szydłowskim, guberni kowieńskiej, został założony w XVII w., dzięki aktowi fundacyjnemu Chryzostoma Wołodkiewicza. Istniał również drewniany kościół parafialny (fara), wybudowany z inicjatywy proboszcza krożskiego księdza Michała Jana Zienkowicza oraz kanonika księdza Tomasza Uwojnia, który jednakże był stary, ciasny, „zmurszały i nadawał się co najwyżej na kaplicę cmentarną".

Notatka o zamknięciu kościola w Krożach w r. 1893, rkps, Zespól Wspólny, Lietuvos Mokslu Akademijos Vrublevskiu Biblioteka, Rankraščiu Skyrius (LMAVB), fond 9, teczka 2362, k. 1. 
zakonnic przebywająca w klasztorze także była pochodzenia szlacheckiego. Liturgia odbywała się po łacinie i po polsku, Ewangelię czytano po polsku i żmudzku, natomiast kazania głoszono wyłącznie po żmudzku. Zakonnice między sobą porozumiewały się po polsku, lecz z krożanami rozmawiały po żmudzku, przez miejscową ludność były bardzo lubiane. Mieszkanka Kroż, Stanisława Januškevičiūte, świadek walki o kościół, wspominała: „Klasztor był zasobny. Biedacy mieli z tego pożytek, klasztor kochali, a zakonnice kochały ludzi. Chociaż one były, jak to teraz powiedzielibyśmy, «Polki», lecz w kościele polskich nabożeństw nie było [...]. Toteż ludzie nie czuli odrazy do murowanego kościoła z powodu jakoby tam panującej polskości - przeciwnie - między kościołem a ludźmi były bliskie powiązania, wzmacniane wspólnotą wiary i poczuciem wzajemnej miłości"'

Mieszkańcy Kroż, nie mogąc pogodzić się z zamknięciem kościoła, w lutym kolejnego roku wysyłali do generała-gubernatora wileńskiego Iwana $\mathrm{Ka}$ chanowa liczne pisma, w których zwracali się z prośbą o oddanie kościoła poklasztornego $i$ zmianę jego statusu na świątynię parafialną ${ }^{8}$. Początkowo wszystko układało się po myśli parafian, jednakże przeciwny ich planom był proboszcz krożański ks. Apolinary Renadzki, „bo niedbały o kościół, miał przede wszystkim ekonomiczne, jak powiada, warunki na względzie: zyskując bowiem dla parafian śliczny kościół, sam nie korzystałby z gruntu, należącego do probostwa"'. W celu rozwikłania tego sporu w sierpniu $1892 \mathrm{r}$. Kachanow wysłał do Kroż dyrektora swojej kancelarii Gołołobowa. Ksiądz Renadzki wręczył mu wówczas podpisaną przez siebie deklarację, zrzekając się w niej prawa do ziemi, na której znajdował się poklasztorny kościół. W tym samym miesiącu, kancelaria generała-gubernatora wileńskiego zwróciła się do władzy duchowej z zapytaniem, zapewne, aby uspokoić rozgorzały thum wiernych, czy wyraziłaby zgodę na utworzenie z krożskiego poklasztornego kościoła - kościoła parafialnego ${ }^{10}$. W odpowiedzi konsystorz orzekł, że nie widzi jakichkolwiek przeciwwskazań. Jednocześnie kościółek drewniany miał zostać zamieniony na filialny.

Tymczasem we wrześniu 1892 r. gubernator Klingenberg poinformował krożan, że wydano rozporządzenie, aby zakonnice przewieźć do Kow-

${ }^{7}$ Amzinininku prisiminimai apie Kražiu skerdynes, w: Kražiu skerdynès/Sudare ir medžiaga surinko L. Mulevicius. Dokumentus vertè ir knygą baigé rengti sp. R. Strazdūnaité, Vilnius 1993, s. $108,111,130$.

${ }^{8}$ Prośba parafian krożańskich z dnia 7 lutego 1892 r., podana na imię Cesarskie, w: [A. Łapiński], Proces Krożan przed izbq sqdowq wileńskq na podstawie aktów sqdowych i innych dokumentów, Kraków 1896, s. 251-252; Prośba parafian krożańskich z dnia 23 lutego 1892 r., na imię wileńskiego, kowieńskiego i grodzieńskiego generat-gubernatora, w: ibidem, s. 253-254; zob. H. Romer, Swoi ludzie, s. 21.

${ }^{9}$ Sprawa krożańska, [Kraków] 1894, s. 3-4.

${ }^{10}$ Z. Nagrodzki, Uwagi do pracy L.[udwiki] Życkiej p.[od] t.[ytulem]: „Krótki rys dziejów tajnej oświaty polskiej na ziemi Wileńskiej 1880-1919”, mpis, LMAVB, Zespót Wspólny, fond 9, teczka 3304, k. 3 
na. Z uwagi na zły stan zdrowia w Krożach zostały Aleksandra Sieliniewska, Benedykta Choromańska, Salomea Siemaszkówna oraz ksieni Michalina Paniewska ${ }^{11}$. Kolejne zmiany nadeszły, gdy nowym generałem-gubernatorem wileńskim został Piotr Wasiljewicz Orżewski. I tak w maju 1893 r., podczas przejazdu przez Kroże, gubernator oddał poklasztorny kościół w zarząd proboszczowi krożańskiemu, a policji nakazał opieczętować pozostałe budynki ${ }^{12}$. Domagał się także, aby władza duchowna zamknęła do 15 października $1893 \mathrm{r}$. klasztor i kościół, w którym odbywało się nabożeństwo. Postanowiono również, wbrew wcześniejszym oczekiwaniom, zamienić kościół przyklasztorny na cerkiew, a wyposażenie świątyni wywieźć ${ }^{13}$. Na polecenie władz naczelnik powiatu rosieńskiego Piotr Wichmann przystapił do likwidacji kościoła. Jednocześnie z klasztoru wywieziono pozostałe w nim zakonnice, które „,dobrowolnie wyjść nie chciały", stąd też sadzano je na krzesło, ,gwałtem wynoszono i pakowano do krytych powozów"14. Parafianie, obserwując działania władz carskich, kierowali kolejne prośby do generała-gubernatora, w których wyrażali pragnienie zamiany kościołów ${ }^{15}$. Orżewski pozostawał nieugięty. Kolejny ukaz, z 10 czerwca 1893 r., stanowił, że fundusze klasztorne powinny być przekazane częściowo na rzecz skarbu rosyjskiego oraz jako wyposażenie cerkwi Zmartwychwstania w Kownie. Materiał z rozbiórki pozostałych nieruchomości posłużyłby na wybudowanie planowanej w Krożach szkoły rolniczej ${ }^{16}$, która w opinii Orżewskiego miała mieć «umoralniające» oddziaływanie na dzieci żmudzkie za pomocą popów i monaszek"17. Konsystorz diecezjalny ad hoc powołał komisję złożoną z dziekana szydłowskiego księdza Jastrzębskiego, proboszcza kielmieńskiego ks. Jawgiela i proboszcza ks. Renadzkiego, narzucając jej członkom, aby oddali dzwony kościelne do pokrożańskiego filialnego kościoła, resztę rzeczy kościelnych nakazał przesłać do katedry kowieńskiej, zaś organy i ołtarz przekazać krożańskiemu proboszczowi.

Jednakże społeczeństwo cały czas czekało na ostateczną rezolucję cara Aleksandra III. Do czasu jej wydania, postanowiono nie wpuszczać nikogo do kościoła, ustanawiając w tym celu stałą straż obywatelską. Już faktycz-

${ }^{11}$ Notatka o zamknięciu kościola w Krożach w r. 1893, k. 2; w chwili zamknięcia kościoła w 1893 r., w klasztorze przebywało dziewięć zakonnic: przełożona Michalina Paniewska, Anatolia Krzyżewiczówna, Katarzyna Bielska, Benedykta Choromańska, Gertruda Kaczanowska, Róża Każdalewiczówna, Ludgarda Wojtkiewiczówna, Aleksandra Sieliniewska oraz Salomea Siemaszkówna. Kapelanem był ksiądz Józef Wierciński.

12 Ibidem, k. 1v.

13 Zob. także: M. Sopoćko, Biskup Stefan Zwierowicz, Wilno 1933, s. 12-13.

14 Sprawa krożańska, s. 5.

${ }^{15}$ Zob. Prośba parafian krożańskich z dnia 29 lutego 1893 r., na imię wileńskiego, kowieńskiego i grodzieńskiego general-gubernatora, w: [A. Łapiński], Proces Krożan, s. 258; Prośba parafian krożańskich z dnia 20 maja 1893 r., na imię wileńskiego, kowieńskiego i grodzieńskiego generalgubernatora, w: ibidem, s. 259.

${ }^{16}$ M. Sopoćko, Biskup Stefan Zwierowicz, s. 22-23; Kroże. Sprawozdanie naocznego świadka o przebiegu procesu, Kraków 1895, s. 9.

${ }^{17}$ Sprawa krożańska, s. 5. 
nie od pierwszych dni września 1893 r. w kościele stale czuwali mieszkańcy miasteczka, a z każdym dniem przybywali wierni z pobliskich parafii. Sytuacja stawała się coraz bardziej napięta i ludzie spodziewali się możliwości rozwiązania siłowego. Źródła w sposób jednoznaczny wskazują że szykowano się do obrony. Wysyłano ponownie delegacje z petycjami oraz listami nie tylko do cara i ministra spraw wewnętrznych, ale także do władców i rządów Austro-Węgier, Rzeszy Niemieckiej, Włoch, Francji, Anglii, Stanów Zjednoczonych i Danii ${ }^{18}$. Do redagowania odpowiednich petycji i wsparcia finansowego znacznie przyczyniło się ziemiaństwo żmudzkie. Do obrony światyni zachęcali też działacze litewskiego ruchu odrodzenia narodowego, najbardziej, oczywiście, młodzi księża. Bez wątpienia powoływano się na doświadczenia lat wcześniejszych. W okresie 1868-1869, biskup żmudzki Maciej Wołonczewski (Motiejus Valančius) wydawał nielegalnie wśród ludu w Tylży książeczki o charakterze religijno-politycznym. To w nich, w sposób bardzo wymowny, a nawet wojowniczy, nakreślił pewien program działań wobec władz rosyjskich, których - według niego - głównym celem była rusyfikacja ludności litewskiej. Dążono do tego, aby Litwini, Żmudzini i Polacy przyjęli mowę, wiarę oraz tożsamość rosyjską. W broszurach bp Wołonczewski w sposób niezwykle precyzyjny przedstawił sytuację Kościoła katolickiego i katolików w Imperium Rosyjskim, zamykanie świątyń i klasztorów, represje wymierzone $\mathrm{w}$ duchowieństwo, a także próby nawracania ludu par force na prawosławie. Toteż biskup, nie podając oczywiście swego autorstwa, nawoływał w pismach do obrony wiary i Kościoła, do postawy otwartego nieposłuszeństwa. Wskazywał, że gdyby „moskale” przyszli odbierać kościoły, wszyscy parafianie powinni zebrać się w środku oraz nie pozwolić „im” się zbliżać. Apelował również o organizowanie nocnego czuwania i modlitwę do Boga, by zachował ich kościół ${ }^{19}$.

Bezpośredni wpływ na postawę krożan miało także pierwsze litewskojęzyczne czasopismo katolicko-narodowe zatytułowane „Žemaičių ir Lietuvos Apžvalga” („Przegląd Żmudzi i Litwy”), w skrócie „Apžvalga”, którego pierwszy numer ukazał się w $1890 \mathrm{r}$. w Tylży. Głównymi redaktorami i autorami artykułów byli aktywni działacze katoliccy: J. Angrabaitis, K. Pakalniškis i P. Urbonavičius. Już na łamach pierwszego numeru redakcja nawoływała tak do sprzeciwu wobec przemocy, jak i do walki o swą wiarę oraz litewskość. Sprawie kasaty klasztoru oraz losu świątyni poświęcono szczególną uwagę. W styczniu 1892 r., w drugim numerze czasopisma, przytoczono dokładną relację ze sprawy kroskiej. Dzięki temu wierni z całej Litwy nawoływani byli do zorganizowania obrony kościoła, nie zważając na czyhające niebezpieczeń-

${ }^{18}$ Kražiu skerdynès/Sudarè ir medžiaga surinko L. Mulevičius, s. 16.

${ }^{19}$ Ibidem, s. 15; V. Merkys, Motiejus Valančius. Tarp katalikiškojo universalizmo ir tautiskumo, Vilnius 1999, s. 725-732. 
stwa ze strony władz ${ }^{20}$. Należy zaznaczyć, że „Apżvalga” kolportowana była także wśród mieszkańców Kroż, co miało bardzo duży wymiar moralny.

Organizatorzy obrony kościoła powoływali się też na podobny casus, jaki wydarzył się przed siedmioma laty. Otóż w $1886 \mathrm{r}$. administracja rosyjska zarządziła kasatę klasztoru męskiego oraz kościoła we wsi Kiestajcie (Kęstaičiai) w powiecie telszewskim. Trzech zakonników i dwóch księży przewieziono do klasztoru w Kretyndze, a majątek ziemski przekazano parafii prawosławnej w Szkudach (Skuodas). Parafianie, obserwując poczynania władz, pragnęli zachować świątynię. W tym celu wysłano delegację do Sankt Petersburga, lecz nie przyniosło to żadnego skutku. Postanowiono więc zebrać się w kościele i bronić go przed zamknięciem oraz zniszczeniem. Czuwano około dwóch miesięcy. W końcu administracja rosyjska na czele $\mathrm{z}$ gubernatorem kowieńskim i z pomocą trzech szwadronów kozaków przybyłych z Worń, przemoca usunęła parafian $\mathrm{z}$ kościoła. Kilku obrońców było rannych, 43 aresztowano i po pewnym czasie, bez śledztwa i wyroku sądowego, zostali zwolnieni ${ }^{21}$. Krożanie także wiedzieli o grożącym im niebezpieczeństwie. Podjęli jednak decyzję, że do końca będą czekać na pomyślne wiadomości z Sankt Petersburga bądź Wilna.

Gubernator Klingenberg, na rozkaz wileńskiego generała-gubernatora Piotra Orżewskiego, 9 listopada 1893 r. udał się do Kroż wraz z żandarmami i policją․ Wcześniej nakazał „trzem sotniom” Kozaków stawić się w umówionym miejscu. W asyście policjantów i żandarmów, uzbrojonych w szable, bicze i rewolwery, wjechał w nocy do miasteczka. Kazał obudzić księży i razem ${ }^{23}$, o drugiej w nocy, wszyscy przybyli przed kościół. U jego bram znajdowało się kilku włościan, którzy pilnowali świątyni. Widząc zbliżające się wojsko, stanęli przed wejściem, trzymając w dłoniach obrazy cesarzowej i cesarza, a także krzyż święty. Argumentowali, że nikt nie ma prawa zabierać im kościoła, dopóki nie przyjdzie odpowiedź od imperatora. Gubernator Klingenberg odpowiedział: „Ja tu właśnie z polecenia cara przychodzę zamknać kościół”. Krożanie ripostowali: „Tyś nie gubernator, ale rozbójnik, żaden gubernator po nocy cesarskich rozkazów nie wykonywa. Nie chcemy żadnych łask ani dobrodziejstw, ino sprawiedliwości. Kościół katolicki tylko do katolików należy". Gubernator dał rozkaz otworzenia świątyni siłą. Zaczęła się przepychanka, wyrywanie krzyża oraz obrazów²4. Pisano: „Uderzeniami

${ }^{20}$ V. Urbonas, Lietuvos žurnalistikos istorija. Periodinê spauda: vadovelis. I Dalis, Klaipèda 2004, s. 75-76; Kun. P. Veblaitis, Krażiu skerdynès, w: Kražiai (monografija), red. P. Razminas, Chicago 1983, s. 43; Kražiu skerdynès/ Sudare ir medžiaga surinko L. Mulevicius, s. 15-16.

${ }^{21}$ P. Čepènas, Naujuiu laiku Lietuvos istorija, s. 139; E. Vidmantas, Religinis tautinis sajūdis Zemaitijoje, s. 127-128; Krażiu skerdynès/Sudare ir medžiaga surinko L. Mulevičius, s. 14.

${ }^{22}$ Paskaita apie Kražiu bažnycios gynima, mpis, Zespót Biblioteki Uniwersyteckiej w Kownie, Różne XVI-Xa, LMAVB, fond 12, teczka 2131, k. 1-2.

${ }^{23}$ Rzeź katolików w Krożach, Warszawa 1894, w: W. Wejtko, Kroże, z. II, Zespól Wspólny, LMAVB, fond 9, teczka 3140, k. $65 \mathrm{v}$.

${ }^{24}$ Ibidem, k. 66. 
knutów po głowie każdego mężczyznę, wychodzącego na cmentarz, jako winowajcę znaczyli uradnicy i wypędzali za oparkanienie; pomimo to, wszystko mogłoby się skończyć spokojnie, gdyby nikczemny gubernator nie wydał nieludzkiego nakazu - knutami siec kobiety, pozostałe w prezbiterium kościelnym, celem szybszego opróżnienia kościoła. Wówczas komisarz Iwanow, wszedłszy z thuszczą pieszych uradników do wnętrza kościoła i spostrzegłszy za kratami prezbiterium kupę modlących się kobiet, $\mathrm{z}$ rewolweru dał w nie strzał, a kula na wylot przeszyła mięśnie nogi [...] służącej ks.[iędza] Renadzkiego, zaś uradnicy poczęli nahajami bić bezbronne kobiety, wlec je za ręce i nogi i wyrzucać z kościoła, gdzie znowu knuty je czekały"25.

Ostatecznie, gdy Rosjanie wtargnęli do środka, ich celem stał się Przenajświętszy Sakrament, który chcieli wynieść ze świątyni. Walka trwała dalej, a szala zwycięstwa stopniowo przechylała się na stronę Krożan. W pewnym momencie gubernator schronił się na chórze, jednakże zdążył przesłać rozkaz do stacjonujących Kozaków, aby natychmiast przybyli z pomoca. Relacjonowano: „Tu go dopadli włościanie i jęli lżyć jako zbója, w nocy napadającego bezbronny lud; pokazywano mu naboje rewolwerowe, zadane rany, a jedna $\mathrm{z}$ kobiet sunęła mu pod nos rozciętą pałaszem rękę i krwią $\mathrm{z}$ niej spływająca zbroczyła mu twarz. Rozżarty tłum chciał zgładzić swego kata; radzono tylko nad tym, jaką śmierć mu zadać: przez wyrzucenie w okno na bruk cmentarny, czyli też przez zawiązanie do worka i utopienie w rzece Krożeńce. Rozsądek jednak przeważył śród tłumu"26. Rozpoczęły się pertraktacje z Klingenbergiem, który spisując z parafianami protokół grał na zwłokę, grymasząc bądź to na niespełniająca jego oczekiwań jakość pióra bądź atrament. Nagle do miasta wtargnęli kozacy i rozpoczęła się swoista rzeź wiernych. Na kartach wspomnień obejmujących te wydarzenia, zanotowano: „Nagle krzyk rozpaczliwy zwiastował, że kozacy przybyli. Przybyli uzbrojeni w karabiny, piki, szable i nahajki i od razu rzucili się na bezbronny lud. Kłuli pikami, strzelali, bili nahajkami po głowie i twarzy. Od każdego uderzenia nahajką krew tryskała. Dwóch kozaków, tratując ludzi, wjechało konno do kościoła i zbroczyło krwią ściany i posadzkę świątyni. Szablami cięli Moskale obrazy w ołtarzach, a krzyże łamali. Wśród tej rzezi, jęków, strumieni krwi, ksiądz Augustyn Możejko przyprowadzony przez kozaków wyniósł z kościoła Przenajświętszy Sakrament. Resztki krzyżów, obrazów i figur świętych wrzucili kozacy do dołu ze śmieciami. Kiedy już kościół został spustoszony, na posadzce zostało kilka trupów i wielu rannych; kozacy wywlekali trupy i wrzucili na cmentarzu do dołu przeznaczonego do gaszenia wapna"27. Zmarłych grzebano natychmiast, bez żadnej indagacji. Księżom zabroniono spisywania nazwisk ofiar i umiesz-

25 Sprawa krożańska, s. 9.

${ }^{26}$ Ibidem, s. 10. Por. też S. Tarnowski, Nasze dzieje w ostatnich stu latach (1794-1894), Kraków 1895, s. 189.

${ }^{27}$ Rzeź katolików w Krożach, z. II, k. 66v-67. 
czania ich w jakichkolwiek metrykach. Nie zezwolono nawet skropić wodą święconą dołów, w których umieszczano ciała. Aresztowane kobiety gwałcono. W innym miejscu pisano: „Ofiar tych zgwałconych było 14. Nieszczęśliwe kobiety, między którymi były dziewczęta, żony i matki, kobiety młode i stare 60-letnie, przemocą zaprowadzili kozacy do różnych domów, poprzednio zrabowanych. Po zgwałceniu obili je i wyrzucili na ulice, grożąc, że gdyby się ośmieliły wrócić i zanieść skargi do oficera [...], to będą knutowane"28.

Następnego dnia odbył się sąd gubernatorski. Na rynku zasiadł gubernator kowieński Klingenberg $w$ asyście policji. Przed jego oblicze przyprowadzano schwytanych włościan, tak mężczyzn, jak i kobiety. Relacjonowano to wydarzenie tymi słowami: „Na rozkaz gubernatora kozacy chwytali po kolei każdego $z$ włościan, rozbierali, rzucali na ziemię, przytrzymywali, a inni stojąc $z$ dwóch stron, bili nahajkami, aż krew tryskała. Nie czyniono wyjątku dla kobiet ciężarnych [...]. Gubernator Klingenberg przyglądał się temu $\mathrm{z}$ uśmiechem wielkiego zadowolenia [...]. Od czasu do czasu zapytywał: Cóż? Gubernator ja jestem, czy rozbójnik? Powiązanych pozamykano do stodół i szynków, które miały służyć za tymczasowe więzienie. Dwie kobiety tam zmarły w nocy z odniesionych ran [...]. Ogółem było trupem pod kopytami koni, od pobicia, od broni i w rzece przeszło sto osób"29. Po tych wydarzeniach gubernator nakazał wydrukować w „Kowieńskich Wiadomościach Gubernialnych” informację, w której usprawiedliwiał działania władz. Argumentował, że kościół na rozkaz cesarza miał być zamknięty i w jego miejscu miano utworzyć szkołę rolniczą. Mieszkańcy na to nie zezwolili, stąd też on zjawił się jako przedstawiciel monarchy z trzema setkami Kozaków. Przy utarczce z ludnością czterech policjantów odniosło lekkie obrażenia - stwierdzał dalej ${ }^{30}$. Należy zaznaczyć, iż w zajściach tych zginęło dziewięć osób, a 54 były ranne, z kolei 69 (52 mężczyzn i 17 kobiet), w wieku od 16 do 80 lat, aresztowano.

Krożanie nie dawali za wygraną. Po nieudanych zabiegach w Petersburgu, wysłali swoich przedstawicieli do króla duńskiego, teścia cara Aleksandra III ${ }^{31}$. Chrystian IX obiecał zapoznać się z całą sprawą. Deputowani wracający z Danii, nie zostali jednak już wpuszczeni przez władze rosyjskie do swojego kraju. Niektórzy udali się do Królestwa Polskiego, zaś inni do Ameryki Północnej ${ }^{32}$. Jak zaznaczyła na kartach swoich wspomnień Wanda Dobaczewska, sprawa krożańska stała się pewnym symbolem walki o swobodę wiary, zaś słowo „Kroże” stanowiło coś w rodzaju hasła ${ }^{33}$.

${ }^{28}$ Ibidem, k. 71

29 Ibidem, k. 68

${ }^{30}$ Ibidem, k. 68v-69; zob. Sprawozdanie urzędowe o wypadkach krożańskich, wydrukowane w ,Kowieńskich wiadomościach gubernialnych", w: [A. Łapiński], Proces Krożan, s. 264.

${ }^{31}$ Zob. J. Kudrina, Impieratrica Marija Fiedorowna Romanowa (1847-1928 gg.), Moskwa 2005, s. 39-43; A. Bohanow, Impierator Aleksandr III, Moskwa 1998, s. 16-19; 503.

Rzeź katolików w Krożach, z. II, k. 69.

${ }^{33}$ W. Dobaczewska, Wilno $i$ Wileńszczyzna w latach 1863-1914, s. 21. 
W dniu 20 września 1894 r., rozpoczął się w wileńskiej izbie sądowej proces krożan, którzy w trakcie walki o kościół, zostali aresztowani. Plac Katedralny u podnóża Góry Zamkowej, oblegał tłum publiczności, oczekujący rychłego rozstrzygnięcia sprawy ${ }^{34}$. Rozprawie przewodniczył naczelny prezes radca tajny Aleksander Stadolskij, zaś komplet sędziowski składał się z radców stanu - Michała Jewreinowa i Pawła Kobeko, radcy kolegialnego Włodzimierza Niekludowa oraz przedstawicieli stanów: Leontjewa - marszałka szlachty powiatu wileńskiego, Gołubinowa - prezydenta miasta Wilna i Dunowskiego - wójta gminy mickuńskiej powiatu wileńskiego ${ }^{35}$. Akt oskarżenia wniósł podprokurator wileńskiej izby sądowej Dobrynin. W obronie krożan z kolei stanęli adwokaci przysięgli okręgowych izb: a) petersburskiej - Andrejewskij, Żukowskij i Turczaninow; b) moskiewskiej - książę Aleksander Urusow; c) warszawskiej - Józef Kamiński ${ }^{36}$; d) wileńskiej - Białyj. Zaś mecenasi Michał Węsławski i Szostakowski bezinteresownie ofiarowali swoją pomoc aresztowanym $^{37}$. Na łamach krakowskiej „Nowej Reformy”, której relacje o procesie przedrukowano po latach w „Przeglądzie Wileńskim”, wskazano na pewne „odchylenia” towarzyszące całej sprawie. W dość obszernym fragmencie pisano bowiem: „Znającemu miejscowe stosunki w oczy bije najprzód anomalia, która wygląda na gorzką ironię losu. Oto oskarżeni o polski bunt, którzy dla kariery Orżewskiego byli bici knutami i prawdopodobnie pójda na Sybir, ani słowa po polsku nie umieją i o Polsce nigdy nie słyszeli, gdyż są prostymi ludźmi i Żmudzinami bez żadnego wykształcenia [...]. Przeciwnie obrusicielami i ciemiężcami - sędziami są przeważnie Polacy lub ludzie polskiego pochodzenia, a co najmniej z Polakami blisko spokrewnieni. I tak generał-gubernator Orżewski jest wnukiem popa unickiego, a więc Polaka, który za objawy polskiego fanatyzmu został wysłany w 1836 roku do guberni połtwaskiej, gdzie wówczas dorosły jego syn, a ojciec Orżewskiego, przyjął prawosławie. Stadolski [...] jest pochodzenia polskiego; Plater jest Polakiem, katolikiem; Klingenberg żonaty z Polka, byłą żoną Brzozowskiego Michała [...]. Na koniec książę Golicyn, który jako potomek Giedyminów pieczętuje się Pogonią litewską, jest żonaty z Polką, warszawianką [...]. Dziwnym trafem losu, a raczej jego ironia, jedyną szlachetną rolę wśród tych brudów i ohydy odgrywają dwaj Moskale z krwi i kości, z których jeden hr.[abia] Zubow, ten, co nie chciał potępiać niewinnych, a drugi rotmistrz żandarmerii Siemionow, ten, co wśród rozwścieczonej tłuszczy siepaczy Klingenberga zasłonił bezbronną staruszkę 80-letnią z narażeniem własnego karku"38.

\footnotetext{
${ }_{34}^{34}$ [A. Lapiński], Proces Krożan, s. 11.

35 Ibidem, s. 12-13.

${ }^{36}$ Poczet prawników polskich $X I X-X X$ w. red. K. Iwaniuk, uzup. A. Redzik, Warszawa 2011,

${ }^{37}$ [A. Lapiński], Proces Krożan, s. 14.

38 Cyt. za: Archiwista [sygn. nierozwiązana], Przyczynki do sprawy krożańskiej, „Przegląd Wileński”, Wilno, 8 XII 1933, nr 21, s. 5-6.
} s. 739 . 
Oskarżonych było 69 , w tym: 33 włościan, 26 przedstawicieli szlachty i 10 mieszczan $^{39}$. Zgodnie z odczytanym aktem oskarżenia, zatrzymanym postawiono zarzuty uniemożliwienia wykonania najwyższego rozkazu, a także stawianie zbrojnego oporu gubernatorowi kowieńskiemu i towarzyszącym mu urzędnikom ${ }^{40}$. Przestępstwa te były przewidziane w artykułach od 263 do 266 rosyjskiego Kodeksu Kar Głównych i Poprawczych. Łącznie odbyło się dziewięć posiedzeń, w dniach od 20 września do 29 września 1894 r., w trakcie których, tak ze strony oskarżenia, jak i obrony, przesłuchano ponad 180 świadków. Na marginesie warto wspomnieć, że głośnym echem odbiła się sprawa proboszcza parafii Wszystkich Świętych oraz św. Anny w Wilnie ks. Łaboka, który w pierwszym dniu rozprawy, apelował do wezwanych świadków, aby zeznawali jedynie prawdę, przypominając o grożącej im karze za krzywoprzysięstwo. W słowach pełnych aluzji pod adresem administracji rosyjskiej, stwierdzał: „Pomnijcie, kończył, jak kara spadła na króla Achaba i żonę jego Jezabel: psy ciało ich szarpały i krew chłeptały za to, że, chcąc przywłaszczyć sobie ojcowiznę Nabota, kazali stanąć fałszywym świadkom, którzy, o złorzeczenie królowi pomawiając niewinnego, przyprawiali go o śmierć i zabór jego własności" ${ }^{11}$. Ostatecznie 29 września 1894 r. w wileńskiej izbie sądowej skazano 36 osób. Cztery z nich na 10 lat ciężkich robót, trzy na zesłanie do guberni tobolskiej, trzy na umieszczenie w domu poprawy, dwie na czteromiesięczne więzienie, sześć na osadzenie w areszcie, trzynaście na trzytygodniowy areszt policyjny, cztery na siedmiodniowy areszt policyjny, jedną zdecydowano się poddać karze domowej ${ }^{42}$. Uzasadnienie wyroku zostało ogłoszone w dniu 8 października $1894 \mathrm{r}^{43}$ Skład orzekajacy wileńskiej izby sądowej argumentował wówczas: „Niezależnie od tego, mając na względzie religijny fanatyzm, nader rozwinięty wśród katolików guberni kowieńskiej w ogóle, a zwłaszcza wśród ludności pochodzenia żmudzkiego, tudzież $\mathrm{i}$ to, że, $\mathrm{z}$ jednej strony, fanatyzm ten z znacznej mierze podniecany był przez rozpowszechnianą wśród ludu gazetę, wydawaną w języku żmudzkim za granicą pod nazwą «Apżvałga», w której wprost nawoływano katolików do otwartego powstania przeciw władzom w tych wypadkach, gdy te uważały zamykać klasztory lub kościoły, a z drugiej strony - że lud w zwłoce, jaka zaszła w zamknięciu kościoła jeszcze na mocy Najwyższego rozkazu z dnia 12 grudnia r.[oku] 1891, nie mógł nie widzieć pewnego poniekąd wahania się władzy, które dawało mu nadzieję ziszczenia jego upragnionych życzeń - osiagnięcia zamiany murowanego kościoła poklasztornego na pa-

39 [A. Łapiński], Proces Krożan, s. 16.

40 Zob. Akt oskarżenia, w: ibidem, s. 18-35.

41 Archiwista [sygn. nierozwiazana], Przyczynki do sprawy krożańskiej, s. 4-5; za te słowa, ks. Labok został pozbawiony probostwa i w marcu 1895 r. skazano go na trzy lata zesłania do Tuły.

${ }^{42}$ [A. Lapiński], Proces Krożan, s. 220-221.

${ }^{43}$ Szerzej zob. Motywy wyroku, w: ibidem, s. 223-239. 
rafialny zamiast drewnianego a zbutwiałego"44. Warto zaznaczyć, że zdanie odrębne w zakresie orzeczonych kar wobec niektórych oskarżonych złożył przedstawiciel stanów Leontjew ${ }^{45}$. Orzeczenie sądowe, w którym za winnych uznano jedynie połowę z ogólnej liczby oskarżonych, świadczyło mimo to o zwycięstwie ówczesnego wileńskiego wymiaru sprawiedliwości, wymierzającemu policzek administracji rosyjskiej. Zbrodni dopuścili się nie krożanie, a główni bohaterowie „,rzezi”: Klingenberg i Orżewski, którzy jednak nie zostali osądzeni.

Pogrom wiernych w Krożach wywołał falę oburzenia w niemalże całej Europie $^{46}$. Być może właśnie dlatego, aby zatrzeć złe wrażenie tych wydarzeń z udziałem władz carskich i roli, jaką odegrał ,satrapa cesarski” Orżewski ${ }^{47}$, w obronie krożan stanęli najlepsi ówcześni rosyjscy adwokaci. Sprawa ta przyczyniła się także do zliberalizowania polityki rosyjskiej względem Kościoła katolickiego i raz jeszcze pokazała, że jedynie współdziałanie dwóch narodów było w stanie przezwyciężyć wszelkie zło i niebezpieczeństwo. Na zakończenie godne przytoczenia są słowa Antoniego Millera, który w swojej powieści zatytułowanej Powolanie, pisał: „Pogrom krożański wywarł wpływ, przynajmniej doraźnie, na poglądy młodej generacji litwomanów [...]. Wszyscy zgodzili się na to, że tragedia krożańska wykazała potrzebę jedności w walce z zakusami wroga; że niezgoda, osłabiając polskość, nie wzmocni ideologii litewskiej i że tylko współpraca Polaków z Litwinami da możliwość równorzędnego rozwijania się dwu kultur na wspólnym terenie, którego bronią od dni pierwszego podziału"48.

44 Ibidem, s. 239.

${ }^{45}$ Zob. Odrębne zdanie, w: ibidem, s. 240-247.

${ }^{46}$ L. Bazylow, Historia Rosji, t. II, Warszawa 1983, s. 391; E. Aleksandravicius, A. Kulakauskas, Pod władzq carów. Litwa w XIX wieku, Kraków 2003, s. 207; J.J. Jadacki, Slawni wilnianie filozofowie, Wilno 1994, s. 175.

${ }_{48}$ Rzeź unitów w Krożach, „Goniec Wileński”, Wilno, 22 XI 1926, nr 4, s. 1.

${ }^{48} \mathrm{~J}$. Miller, Powolanie. Powieść osnuta na tle stosunków kleru polsko-litewskiego na Litwie, Warszawa-Wilno 1919-1927, s. 229. 
